\title{
ZAKAT SEBAGAI PENGURANG PENGHASILAN KENA PAJAK
}

\author{
Nanda Suryadi \\ Fakultas Ekonomi dan Ilmu Sosial \\ Universitas Islam Negeri Sultan Syarif Kasim Riau \\ e-mail: nanda.suryadi@uin-suska.ac.id
}

\begin{abstract}
Abstrak: Zakat memiliki peranan penting bagi kepedulian sosial seorang Muslim dimana dalam sebagian hartanya ada yang merupakan hak orang lain yang wajib dikeluarkannya yang sesuai dengan ketentuan Undang-undang No. 38 Tahun 1999. Zakat merupakan ibadah yang bukan hanya berdimensi vertikal antara seorang Muslim dengan Allah Swt, namun zakat juga merupakan bentuk kepedulian sosial seorang Muslim. Pelaksanaan zakat sebagai pengurang penghasilan kena pajak yang dilaksanakan di Kota Pekanbaru sudah terlaksana akan tetapi pengurangan pajak bagi pembayar zakat masih minim dilakukan oleh wajib pajak orang pribadi, salah satu penyebabnya yaitu bagi wajib pajak yang tahu akan aturan tentang perlakuan zakat atas penghasilan dalam perhitungan penghasilan kena pajak tetapi mereka cenderung belum bisa melaksanakannya karena hal tersebut dianggap merepotkan. Sementara bagi wajib pajak yang belum tahu karena belum adanya sosialisasi secara umum akan adanya pengurangan pajak bagi pembayar zakat yang dibentuk dan disahkan oleh pemerintah. Disarankan bagi pemerintah untuk gencar melakukan sosialisasi mengenai penerapan zakat sebagai pengurang penghasil kena pajak.
\end{abstract}

Kata Kunci: Zakat, Penghasilan Kena Pajak. 


\section{PENDAHULUAN}

Zakat salah satu rukun Islam yang kewajibannya bersifat mutlak atas harta kekayaan seseorang menurut aturan yang telah di tetapkan dalam Al- Qur'an dan Hadis. Dalam konteks negara modern, zakat bukanlah pajak yang merupakan salah satu sumber pendapatan negara. Zakat di pandang sebagai sarana komunikasi utama antara orang kaya dengan orang miskin, yang memiliki peranan sangat penting sebagai sarana distribusi penghasilan dalam menata tata kehidupan bermasyarakat yang sejahtera, berkeadilan di dalam sebuah negara.

Kedudukan zakat dalam Islam suatu keunggulan dalam sistem ekonomi Islam. Zakat menggambarkan perwujudan ketaatan seorang Muslim terhadap Sang Khaliq. Hal ini merupakan suatu penjelmaan dari solidaritas seorang Muslim dalam kehidupan bermasyarakat. Jadi jika shalat berusaha membentuk keshalehan pribadi individu, maka zakat berperan membentuk keshalehan sosial bagi setiap individu dalam masysrakat.

Pajak adalah iuran rakyat kepada penguasa negara berdasarkan undangundang (yang dapat dipaksakan) dengan tidak mendapat jasa imbal (kontrprestasi) yang langsung dapat ditunjukkan dan yang digunakan untuk membayar pengeluaran umum. Korelasi antara zakat dan pajak sama-sama mempunyai fungsi pemungutan dalam kehidupan bernegara.

Pada zakat, fungsi pemungutan dapat dilakukan oleh orang yang terkena kewajiban membayar zakat dan dapat langsung disalurkan kepada orang yang berhak menerimanya atau dilakukan oleh suatu badan atau lembaga resmi seperti Badan Amil Zakat (BAZ) atau Lembaga Amil Zakat (LAZ) yang di bentuk oleh pemerintah untuk memungut zakat serta mendistribusikan kepada delapan golongan yang berhak menerima zakat. Sedangkan dalam pajak, fungsi pemungutannya dilakukan oleh negara melalui Dirjen Pajak. Menurut ajaran Islam, zakat sebaiknya dipungut oleh negara dan atas nama pemerintah yang bertindak sebagai wakil fakir miskin.

Fakta bahwa subjek pajak terbesar adalah kaum Muslim yang jumlahnya $87 \%$ dari total penduduk Indonesia, pemerintah berupaya untuk meminimalkan kewajiban ganda yang memberatkan. Untuk mengatasinya dilakukan upaya titik temu antara pajak dan zakat sehingga kedua kewajiban tersebut dapat dilaksanakan oleh umat Islam tanpa memberatkannya.

Pemerintah membuat aturan yang dapat menjadi solusi bagi kewajiban ganda yaitu zakat dan pajak yang dialami oleh umat Islam. Hal ini dicantumkan dalam pasal 22 Undang-undang No.23 Tahun 2011 atas perubahan pasal 14 ayat 3 Undang-undang No.38 Tahun 1999 Tentang Pengelolaan Zakat, disebutkan bahwa zakat yang telah dibayarkan kepada badan amil zakat atau lembaga amil zakat dikurangkan dari laba/pendapatan sisa kena pajak dari wajib pajak yang bersangkutan sesuai dengan peraturan perundangundangan yang berlaku.

Undang-undang ini menunjukkan bahwa pemerintah mencoba untuk berperan aktif dalam menciptakan pelaksanaan kewajiban keagamaan masyarakatnya dengan menjadikan unsur zakat sebagai salah satu tax relief (keringanan pajak) dalam pemungutan Pajak Penghasilan $(\mathrm{PPh})$ di Indonesia. Saat ini undang-undang menjadikan zakat sebagai salah satu faktor pengurang penghasilan neto wajib pajak 
Orang Pribadi (WPOP) dalam menentukan besarnya Penghasilan Kena Pajak. Hal ini diharapkan dapat meminimalkan beban ganda yang dipikul oleh umat Islam sebagai wajib pajak dan muzakki. Jika di lihat dari fungsi dasarnya membayar zakat bisa disamakan nilainya dengan membayar pajak yakni sama-sama dimaksudkan untuk melaksanakan kewajiban yang bertujuan untuk kemaslahatan ummat dan bangsa.

Melihat kenyataan di atas, bahwa pemerintah telah mengeluarkan undangundang sebagai solusi dari beban ganda yang dirasakan ummat Islam yang saat ini belum terealisasi dengan baik dan besarnya potensi dana zakat di Indonesia, maka peneliti tertarik meneliti tentang "Peranan Zakat Sebagai Pengurang Penghasilan Kena Pajak."

\section{TINJAUAN PUSTAKA Pengertian Zakat}

Menurut bahasa zakat artinya
tumbuh dan berkembang, atau menyucikan karena zakat akan mengembangkan pahala pelakunya dan membersihkannya dari dosa. Menurut syariat, zakat ialah hak wajib dari harta tertentu pada waktu tertentu.

Menurut Asy-Syaukani, zakat adalah pemberian sebagian harta yang telah mencapai nishab kepada orang fakir dan sebagainya dan tidak mempunyai sifat yang dapat dicegah syara' untuk mentasharufkan kepadanya (Ashshiddiqy, 2009).

Zakat adalah nama suatu ibadah wajib yang dilaksanakan dengan memberikan sejumlah kadar tertentu dari harta milik sendiri kepada orang yang berhak menerimanya menurut yang ditentukan syariat Islam (Sari, 2006).
Dari beberapa pengertian di atas, maka dapat diambil kesimpulan bahwa zakat merupakan harta umat untuk umat, dari orang yang wajib membayarnya kepada orang yang berhak menerimanya. Zakat dapat membersihkan jiwa para muzakki dari sifat-sifat kikir, tamak serta membersihkan diri dari dosa dan sekaligus menghilangkan rasa iri dan dengki si miskin kepada si kaya. Dengan zakat dapat membentuk masyarakat makmur dan menumbuhkan penghidupan yang serba berkecukupan.

\section{Dasar Hukum Zakat}

Zakat merupakan ibadah yang diwajibkan kepada setiap Muslim yang berkaitan dengan harta dengan syaratsyarat tertentu. Dasar hukum kewajiban mengeluarkan zakat diterangkan dalam Surah Al-Baqarah ayat 43:

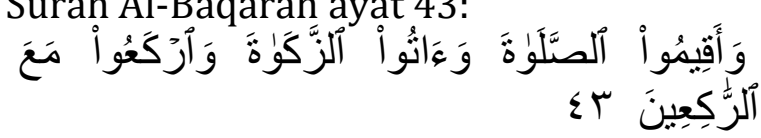

Artinya: "Dan dirikanlah shalat, tunaikanlah zakat dan ruku'lah beserta orang-orang yang ruku".

Dan juga dalam Surah At-Taubah ayat 103:

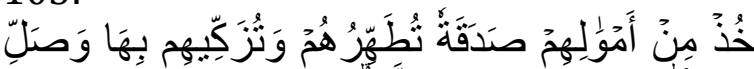

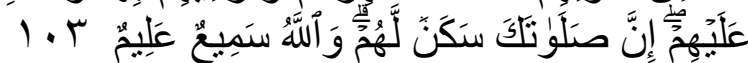
Artinya: Ambillah zakat dari sebagian harta mereka, dengan zakat itu kamu membersihkan dan mensucikan mereka dan mendo'alah untuk mereka. Sesungguhnya doa kamu itu (menjadi) ketenteraman jiwa bagi mereka. Dan Allah Maha Mendengar lagi Maha Mengetahui.

Selain dasar hukum Al- Qur'an terdapat hadis dari Ibnu abbas ra., bahwa rasulullah ketika mengirim Mujaz ibn Jaba ke negeri Yaman, bersabda: 
Artinya: "Dari Ibnu Abbas r.a., sesungguhnya rasulullah telah mengutus Mu'adz bin Jabal ke negeri Yaman. Nabi Muhammad SAW bersabda: Serulah (ajaklah) mereka untuk mengakui bahwa tidak ada Tuhan selain Allah dan bahwa saya (Muhammad)adalah utusan Allah. Jika mereka telah menerima itu maka beritahukan bahwa Allah telah mewajibkan shalat lima waktu dalam sehari semalam. Jika hal ini telah mereka taati, sampaikanlah bahwa Allah ta'ala mewajibkan atas mereka zakat yang diambil dari orang-orang mereka, dan diberikan kepada orang fakir meraka."

Dengan dasar hukum tersebut zakat merupakan ibadah sosial yang wajib dilaksanakan oleh umat islam dengan syarat-syarat tertentu. Selain AlQur'an dan hadis terdapat juga dasar hukum formal yang dibuat oleh pemerintah tentang pengelolaan zakat seperti Undang-Undang No.23 Tahun 2011 tentang pengelolaan zakat dan pengelolaan zakat ini juga diatur dalam PSAK 109 Akuntansi Zakat, infak, dan shadaqoh.

\section{Konsep Pajak}

Pengertian pajak menurut P.J.A. Andriani dikutip oleh Apriliana (2009), pajak merupakan iuran kepada negara (yang dapat dipaksakan) yang terhutang menurut peraturan perUndangUndangan tanpa mendapat prestasi kembali yang langsung dapat ditunjuk dan digunakan untuk membiayai pengeluaran umum sehubungan dengan tugas negara untuk menyelenggarakan pemerintahan.

Menurut Rochmat Soemitro dalam bukunya dasar-dasar hukum pajak dan pajak pendapatan yang di kutip oleh Apriliana (2009), pajak adalah iuran rakyat kepada penguasa negara berdasarkan Undang- Undang (yang dapat dipaksakan) dengan tidak mendapat jasa imbal (kontrprestasi) yang langsung dapat ditunjukkan dan yang digunakan untuk membayar pengeluaran umum.

Secara konstitusional pajak adalah salah satu sumber penerimaan negara yang sah dan dikukuhkan dalam UUD 1945 Pasal 23A, yang menyebutkan bahwa, pajak dan pungutan lain yang bersifat memaksa untuk keperluan negara.

\section{Sistem Pemungutan Pajak}

Pemungutan pajak yang diterapkan tercermin dalam undang-undang pajak yaitu: official assessment system, semi self assessment system, self assessment system, dan withholding system. Maksud undangudang pajak di atas yaitu: Official Assesment System adalah suatu sistem pemungutan pajak yang memberi wewenang kepada pemungut pajak (fiskus) untuk menentukan besarnya pajak yang harus dibayar (pajak yang terhutang) oleh seseorang. Semi Self Assesment system adalah suatu sistem pemungutan pajak yang hampir sama dengan official assessment system.

Sistem ini setiap tahun wajib pajak menentukan sendiri besarnya pajak yang terhutang untuk tahun berjalan Self Assessment System adalah suatu sistem pemungutan pajak yang memberi wewenang penuh kepada wajib pajak untuk menghitung, menyetorkan dan melaporkan sendiri besarnya utang pajak. Witholding System adalah suatu sistem pemungutan pajak yang memberi wewenang pada pihak ketiga untuk memungut besarnya pajak yang terutang.

\section{Penghasilan Kena Pajak}

Pengenaan Zakat untuk $\mathrm{W}$ a j i b Pajak Orang Pribadi (WPOP) sebagai pengurang penghasilan Kena 
Pajak, hal ini sesuai dengan Undangundang No. 36 Tahun 2008 Tentang Pajak Penghasilan dan Undang-udang No. 38 Tahun 1999 Tentang Pengelolaan Pajak. Format pengenaan zakat yang digunakan untuk $\mathrm{Wajib}$ Pajak Orang Pribadi (WPOP) jika dikurangkan dari Penghasilan Kena Pajak (PKP) dirincikan dalam tabel berikut ini:

Tabel 1.Format Pengenaan Pajak dan Zakat untuk Wajib Pajak Orang Pribadi

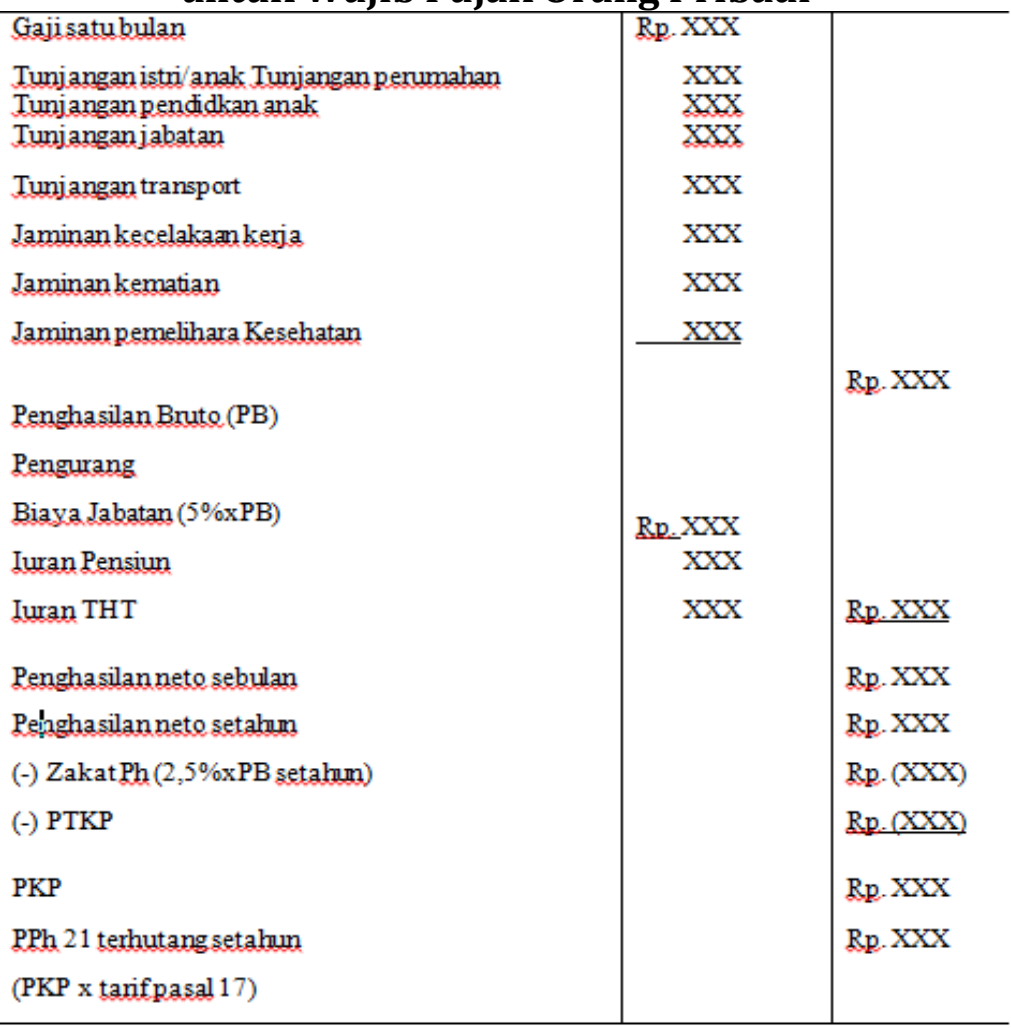

Tabel 1 di atas menggambarkan cara menghitung pengenaan pajak dan zakat Wajib Pajak Orang Prib a d i (WPOP) untuk mendapatkan bukti atau hasil diterapkannya zakat sebagai pengurang Penghasilan Kena Pajak setelah dikurangkan dengan Penghasilan Tidak Kena Pajak. Pengenaan Zakat untuk Wajib Pajak Orang Pribadi (WPOP) dikurangkan dari
Penghasilan Kena Pajak, hal ini sesuai dengan Undang-undang No. 36 Tahun 2008 Tentang Pajak Penghasilan dan Undang-undang No. 36 Tahun 1999 Tentang Pengelolaan Zakat. Untuk penghasilan Tidak Kena Pajak (PTKP) per tahun sesuai dengan pasal 7 Undangundang No. 36 Tahun 2008 Tentang Pajak Penghasilan adalah:

Tabel 2. Penghasilan Tidak Kena Pajak (PTKP)

\begin{tabular}{l|l}
\hline Rp. 15.840 .000 & Untuk diri Wajib Pajak Orang Pribadi (WPOP) \\
\hline Rp. 1.320 .000 & Tambahan untuk Wajib Pajak menikah \\
\hline
\end{tabular}




\begin{tabular}{l|l}
\hline Rp. 15.840 .000 & $\begin{array}{l}\text { Tambahan untuk seorang istri yang penghasilannya } \\
\text { digabung dengan penghasilan suami }\end{array}$ \\
\hline Rp. 1.320 .000 & $\begin{array}{l}\text { Tambahan untuk setiap anggota keluarga sedarah } \\
\text { dan keluarga semenda dalam garis keturunan lurus } \\
\text { serta anak angkat, yang menjadi tanggungan } \\
\text { sepenuhnya, paling banyak tiga orang untuk setiap } \\
\text { keluarga }\end{array}$ \\
\hline
\end{tabular}

Sumber: Undang-Undang Nomor 38 Tahun 2008.

Tabel 2 di atas berisi tentang besarnya jumlah penghasilan yang tidak kena pajak (PTKP) dan aspek-aspeknya. Selain Penghasilan Tidak Kena Pajak, tarif pajak juga berpengaruh dalam perhitungan Zakat sebagai pengurang
Penghasilan Kena Pajak, maka perlu di uraikan tarif pajak yang diterapkan atas Penghasilan Kena Pajak (PKP) bagi Wajib Pajak Orang Pribadi (WPOP). Rinciannya dapat dilihat dalam tabel sebagai berikut:

Tabel 3.Tarif Pajak Pasal 17

\begin{tabular}{l|c}
\hline \multicolumn{1}{c|}{ Lapisan PKP } & Tarif Pajak \\
\hline Sampai dengan Rp. 50.000.000 & $5 \%$ \\
\hline Diatas Rp. 50.000.000 s/d Rp. 250.000.000 & $15 \%$ \\
\hline Diatas Rp. 250.000.000 s/d Rp. 500.000.000 & $25 \%$ \\
\hline Diatas Rp. 500.000.000 & $30 \%$ \\
\hline
\end{tabular}

Sumber : Undang-Undang Nomor 36 Tahun 2008.

\section{PEMBAHASAN}

\section{Pajak dalam Pandangan Islam}

Menurut Ilfi yang di kutip oleh Andriani dan Fatha Fathya (2013), bahwa dalam peradaban Islam di kenal dua lembaga yang menjadi pilar kesejahteraan masyarakat dan kemakmuran negara yaitu Lembaga Zakat dan Lembaga Pajak karena sifatnya adalah wajib. Pada prinsipnya zakat dan pajak adalah dua kewajiban yang mempunyai dasar berpijak berlainan.

Zakat mengacu pada ketentuan syariat Islam, sedangkan pajak berpijak pada peraturan perundang-undangan yang ditentukan oleh Ulil Amri (pemerintah) menyangkut pemungutan maupun penggunaannya. Ummat Islam sejak abad pertama hijriyah telah mengenal pajak dengan sebutan kharaj (pajak hasil bumi/tanaman), sedang pajak dalam pengertian umum disebut dharibah. Dalam Islam pajak terdiri atas Kharaj (pajak bumi/tanaman), Usyur (pajak perdagangan/bea cukai), dan Jizyah (pajak jiwa terhadap nonMuslim yang hidup di dalam naungan pemerintahan Islam).

\section{Hubungan Antara Zakat Dengan Pajak} Zakat dan pajak berkorelasi satu sama lain, namun keduanya berbeda dalam beberapa hal. Di antara titik persamaan antara zakat dan pajak adalah sama-sama bersifat memaksa, melibatkan pengelola dan tujuan kesejahteraan bersama.

Tujuan zakat dan pajak adalah untuk menekan kesenjangan sosial ekonomi dalam masyarakat dan melakukan pemerataan harta 
kepemilikan untuk kesejahteraan bersama. Zakat dan Pajak keduanya mengandung beberapa aspek perbedaan, yaitu pada sisi penamaan, dasar hukum dan sifat kewajiban. Dari segi penamaan, zakat berarti bersih, suci, berkah, tumbuh, maslahat, dan berkembang. Sementara pajak, berasal dari kata dharibah yang secara etimologis berarti beban dan kadangkala diartikan pula dengan jizyah yang berarti pajak tanah (upeti) yang diserahkan oleh ahli zimmah (orang yang tetap dalam kekafiran tetapi tunduk pada aturan pemerintah Islam).

\section{Persamaan Pajak dan Zakat}

Berdasarkan penjelasan di atas, persamaan antara zakat dengan pajak adalah pada unsur paksaan dan kewajiban yang merupakan cara untuk menghasilkan pajak, juga terdapat dalam zakat. Bila pajak harus di setor kepada negara, pusat maupun daerah, maka zakat pun demikian. Karena pada dasarnya zakat itu harus diserahkan kepada pemerintah sebagai badan yang disebut Lembaga Amil Zakat (LAZ) atau Badan Amil Zakat (BAZ).

Pada ketentuan pajak tidak ada imbalan tertentu. Para wajib pajak menyerahkan pajaknya selaku anggota masyarakat. Ia hanya memperoleh berbagai fasilitas untuk dapat melangsungkan kegiatan usahanya. Pajak pada zaman modern ini mempunyai tujuan ke masyarakat, ekonomi dan politik di samping tujuan keuangan, maka zakat mempunyai tujuan yang lebih jauh dan jangkauan yang lebih luas dari pada aspek-aspek tersebut.

$\begin{array}{lr}\text { Ketentuan Zakat dalam } & \text { Undang- } \\ \text { Undang Perpajakan } & \\ \text { Reformasi } & \text { peraturan } \\ \text { perpajakan mengenai } & \text { zakat }\end{array}$

dilakukan oleh pemerintah untuk mendorong wajib pajak dan muzakki agar dapat menunaikan kewajiban membayar pajak penghasilan dan zakat penghasilan dengan baik. Untuk mengatasinya pemerintah telah melakukan integralisasi antara kewajiban pajak dan zakat. Pada Pasal 9 ayat (1) huruf g Undang- undang Nomor 36 Tahun 2008 tentang Pajak penghasilan telah mengkomodir zakat bahwa:

Untuk menentukan besarnya Penghasilan Kena Pajak bagi Wajib Pajak dalam dalam negeri dan bentuk usaha tetap tidak boleh dikurangkan dari harta yang dihibahkan, bantuan atau sumbangan dan warisan, kecuali sumbangan sebagaimana dimaksud dalam pasal 6 ayat (1) huruf I sampai m serta zakat yang di terima oleh Badan Amil Zakat atau Lembaga Amil Zakat yang di bentuk atau disahkan oleh pemerintah atau sumbangan keagamaan yang sifatnya wajib bagi pemeluk agama yang diakui di Indonesia, yang di terima oleh lembaga keagamaan yang di bentuk atau disahkan oleh pemerintah.

Termasuk pula dalam Pasal 14 ayat (3) Undang-undang Nomor 38 Tahun 1999 Tentang pengelolaan zakat menyatakan bahwa, zakat yang telah dibayarkan kepada Badan Amil Zakat atau Lembaga Amil Zakat dapat dikurangkan dari laba atau pendapatan sisa kena pajak dari wajib pajak yang bersangkutan.

Dari kedua undang-undang ini dapat disimpulkan bahwa perlakuan zakat yang berlaku di Indonesia saat ini yaitu zakat sebagai pengurang Penghasilan Kena Pajak (PKP). Selama ini di kalangan ummat islam beredar anggapan yang salah, bahwa membayar 
zakat dapat langsung mengurangi pajak yang akan dibayar.

\section{Penerapan Zakat Sebagai Pengurang Penghasilan Kena Pajak}

Kebijakan Zakat sebagai pengurang Penghasilan Kena Pajak di atur dalam Undang-undang Republik Indonesia No. 36 Tahun 2008 tentang Pajak Penghasilan dan Undang-undang No. 23 Tahun 2011 Perubahan atas Undang-undang No. 38 Tahun 1999 Tentang Pengelolaan Zakat serta Keputusan Direktur Jendral Pajak dengan Nomor KEP- 163/PJ/2003 mengenai Perlakuan Zakat dikurangkan dari Penghasilan dalam Penghitungan Penghasilan Kena Pajak atas Pajak Penghasilan.

Mengenai pelaksanaan pengelolaan zakat tentunya tidak dapat dipisahkan dari sebuah ukuran akan berhasil atau tidaknya pengelolaan zakat tersebut. Keberhasilan dalam pengelolaan zakat di tentukan dari strategi dan manfaat zakat bagi mustahik. Keberhasilan pengelolaan zakat dapat dilihat dari adanya perubahan peran seseorang, dari yang awalnya menjadi mustahik berdaya dan beralih menjadi seorang muzzaki.

Untuk merubah peran seseorang mustahik dari yang dibantu menjadi yang membantu muzzaki dalam zakat ditentukan oleh strategi dan program pendistribusian yang dilakukan oleh pengelola Zakat. Pengelolaan zakat menjadi suatu hal yang penting karena keberhasilan ini hanya dapat dicapai dengan pola pengelolaan zakat secara efektif produktif.

\section{SIMPULAN}

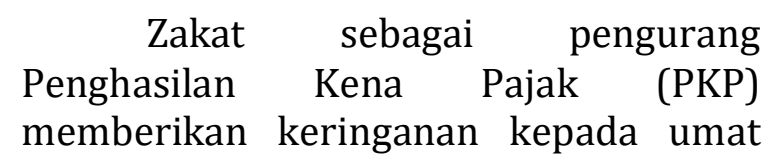

Islam dalam membayar zakat dan pajak juga meningkatkan kesadaran dan kejujuran dalam diri masyarakat untuk membayar zakat, dengan kesadaran masyarakat membayar zakat dan pajak maka akan semakin meningkat muzakki dan sudah tentu akan meningkatkan pendapatan Negara. Oleh karena itu, disarankan bagi pemerintah untuk gencar melakukan sosialisasi mengenai penerapan zakat sebagai pengurang penghasil kena pajak.

\section{DAFTAR RUJUKAN}

Andriani, S., \& Fathya, F. (2013). Zakat Sebagai Pengurang Pajak Penghasilan Pada Badan Amil Zakat. JRAK: Jurnal Riset Akuntansi dan Komputerisasi Akuntansi, 4(1), 13-32

Apriliana. (2010). Analisis Komparatif Antara Perlakuan Zakat Sebagai Pengurang Penghasilan Kena pajak Dengan Perlakuan Zakat Sebagai Pengurang Langsung Pajak Penghasilan. Skripsi. UIN Syarif Hidayatullah. Jakarta.

Ash-Shiddiqy, Teuku Muhammad Hasby. (2009). Pedoman Zakat. Semarang: PT. Pustaka Rizki Putra.

Sari, Elsa Kartika. (2006). Pengantar Hukum Zakat dan Wakaf, Jakarta: PT. Grasindo. 